\title{
Memahami Gagasan Anything Goes Paul Karl Feyerabend dan Implikasinya terhadap Pendidikan Islam
}

\author{
Dandy Sobron Muhyiddin ${ }^{1}$, Nanat Fatah Natsir ${ }^{2}$, Erni Haryanti ${ }^{3}$ \\ 1,2,3Universitas Islam Negeri Sunan Gunung Djati Bandung, Indonesia \\ E-mail: dandysobronm@gmail.com, nanatfatahnatsir@uinsgd.ac.id, erni hk@uinsgd.ac.id
}

\begin{tabular}{l}
\hline Article Info \\
\hline Article History \\
Received: 2021-11-20 \\
Revised: 2021-12-15 \\
Published: 2022-01-14
\end{tabular}

Keywords: Anything Goes;

Paul Karl Feyerabend; Islamic;

Education.
Published: 2022-01-14

\begin{abstract}
This research explains about understanding Paul Karl Feyerabend's idea of anything goes and its implications for Islamic education. The method used in this study uses a library research method or approach, that library research can be interpreted as a series of activities related to the methods of collecting library data, reading and taking notes and processing research materials. The results of this study indicate that Feyerabend's idea is called epistemological anarchism, which is an epistemological theory that has the view that there are no methodological rules for the development of science. Science must be developed through universal regulation without destroying or limiting science itself. According to Feyerabend, there is no need to falsify a theory to find the truth, but rather by trying to find new theories that are built, developed, and maintained (theoretical pluralism). Theoretical pluralism is important to avoid uniformity that limits critical thinking. The idea of anything goes is put forward that any hypothesis can be used, including those that are unreasonably acceptable or deviate from general theory and emerge from the experimental process. Feyerabend emphasized that scientific progress is not only determined by inductive processes like ordinary science, but also counterinductively. Feyerabend's idea of epistemological anarchism could influence the development of Islamic education. With the principle of anything goes in his thinking, one can eliminate or at least reduce the occurrence of monopoly from one method to another.
\end{abstract}

\begin{tabular}{l}
\hline Artikel Info \\
\hline Sejarah Artikel \\
Diterima: 2021-11-20 \\
Direvisi: 2021-12-15 \\
Dipublikasi: 2022-01-14
\end{tabular}

Kata kunci: Anything Goes; Paul Karl Feyerabend; Pendidikan; Islam.

\begin{abstract}
Abstrak
Penelitian ini menjelaskan tentang memahami gagasan anything goes Paul Karl Feyerabend dan implikasinya terhadap pendidikan islam. Metode yang digunakan dalam kajian ini menggunakan metode atau pendekatan kepustakaan (library research), bahwa studi pustaka atau kepustakaan dapat diartikan sebagai serangkaian kegiatan yang berkenaan dengan metode pengumpulan data pustaka, membaca dan mencatat serta mengolah bahan penelitian. Hasil penelitian ini menunjukkan bahwa gagasan Feyerabend yang disebut anarkisme epistemologis, yaitu suatu teori epistemologi yang memiliki pandangan tidak ada aturan metodologis untuk pengembangan sains. Sains harus dikembangkan melalui regulasi universal tanpa merusak atau membatasi sains itu sendiri. Menurut Feyerabend, tidak perlu falsifikasi suatu teori untuk menemukan kebenaran, melainkan dengan mencoba menemukan teori-teori baru yang dibangun, dikembangkan, dan dipertahakan (theoretical pluralism). Pluralisme teori penting untuk menghindari keseragaman yang membatasi berpikir kritis. Gagasan anything goes dikemukakan bahwa hipotesis apa pun dapat digunakan, termasuk yang tidak wajar dapat diterima atau menyimpang dari teori umum dan muncul dari proses eksperimental. Feyerabend menekankan bahwa kemajuan ilmiah tidak hanya ditentukan oleh proses induktif seperti sains biasa, tetapi juga secara kontrainduktif. Gagasan Feyerabend tentang anarkisme epistemologis bisa berpengaruh pada pengembangan pendidikan Islam. Dengan prinsip anything goes dalam pemikirannya, seseorang dapat menghilangkan atau setidaknya mengurangi terjadinya monopoli dari satu metode ke metode lainnya.
\end{abstract}

\section{PENDAHULUAN}

Ilmu pengetahuan sangat penting bagi manusia. Dengan ilmu, kita dapat memenuhi segala kebutuhan dan kebutuhan manusia dengan cepat dan mudah. Dan merupakan fakta yang tak terbantahkan bahwa peradaban manusia mendapat manfaat dari sains. Ilmu pengetahuan telah mengubah wajah dunia, misalnya dengan memberantas penyakit, kelaparan, kemiskinan, dan banyak aspek kehidupan yang sulit lainnya (Irwansyah, 2021). Dengan kemajuan ilmu pengetahuan, masyarakat juga dapat merasakan kemudahan lain seperti transportasi, pembayaran, pendidikan dan komunikasi (Arifudin, 
2020). Singkatnya, sains adalah sarana untuk membantu orang mencapai tujuan hidup mereka.

Dewasa ini ilmu bahkan sudah berada diambang kemajuan yang mempengaruhi reproduksi dan penciptaan manusia itu sendiri. Ilmu bukan lagi merupakan sarana yang membantu manusia mencapai tujuan hidupnya, namun bahkan kemungkinan mengubah hakikat kemanusiaan itu sendiri. Sebenarnya sejak saat pertumbuhannya ilmu sudah terkait dengan masalahmasalah moral namun dalam perspektif atau pandangan yang berbeda, Darsono dalam (Sofyan, 2020) mengemukakan moral adalah sistem nilai (sesuatu yang dijunjung tinggi) yang berupa ajaran (agama) dan paham (ideologi) sebagai pedoman untuk bersikap dan bertindak baik yang diwariskan dari generasi ke generasi berikutnya. Tujuan moral adalah mengarahkan sikap dan perilaku manusia agar menjadi baik sesuai dengan ajaran dan paham yang dianutnya (Na'im, 2021). Manfaat moral adalah menjadi pedoman untuk bersikap dan bertindak atau berperilaku dalam interaksi sosial yang dinilai baik atau buruk (Ulfah, 2022). Tanpa memiliki moral, seseorang akan bertindak menyimpang dari norma dan nilai sosial dimana mereka hidup dan mencari penghidupan.

Peranan penting sebuah konsep ilmu pengetahuan dalam menentukan warna dan arah tindakan manusia sudah sejak lama menjadi fokus epistemik diskursus filsafat. Thomas Kuhn, seorang ahli sejarah ilmu pengetahuan, mengemukakan dalilnya bahwa suatu teori ilmu pengetahuan sering menimbulkan sikap militan dalam kalangan penganutnya untuk membelanya. Hal ini disebabkan karena selain isi empirisnya, ada semacam metaphysical underlay dalam setiap teori, yang berhubung dengan pandangan dunia dan pandangan hidup seseorang (Kuhn, 1962). Berubahnya sebuah teori ilmu pengetahuan niscaya berubahnya pandangan dunia dan pandangan hidup seseorang (Bairizki, 2021).

Dengan demikian tidaklah mengherankan jika sebuah konsep ilmu pengetahuan keberadaanya mengalami pasang-surut. Pada momen tertentu, sebuah konsep diterima, dibela dan diagungagungkan oleh mayoritas masyarakat dunia, tetapi pada momen lain, ia justru dikritik dan ditinggalkan untuk kemudian digantikan oleh konsep baru. Menurut (Popper, 1986), setiap teori harus melalui proses falsifikasi untuk menemukan teori yang benar. Bila suatu teori dapat ditemukan titik lemahnya maka teori tersebut gugur. Pergeseran paradigma semacam itu bergantung pada penerimaan masyarakat (social acceptance). Proses semacam itulah yang disebut oleh Kuhn sebagai shifting paradigm.

Disisi yang berseberangan, Feyerabend menggabungkan konsep yang berbeda. Feyerabend berpendapat bahwa untuk menemukan teori yang benar, suatu teori tidaklah harus dicari kesalahannya (falsifikasi) melainkan mengkonstruksi sebanyak mungkin teori-teori baru dan mempertahankannya. Pada awalnya, sebagai murid Popper, Feyerabend mendukung filosofi dan prinsip falsifikasi Popper namun kemudian dia berbalik menjadi salah seorang penentang Popper. Feyerabend berpendapat bahwa prinsip falsifikasi Popper tidak dapat dijalankan sebagai satu-satunya metode ilmiah untuk kemajuan ilmu pengetahuan (Feyerabend, 1975).

Tidak seperti Kuhn yang mengemukakan shifting paradigm dalam revolusi ilmu pengetahuan, Feyerabend tidak menganggap suatu metode baru menggantikan metode sebelumnya yang terbukti salah melalui falsifikasi. Meskipun sebuah metode melalui falsifikasi terbukti tidak sesuai dengan fakta yang tertentu, tidak berarti metode tersebut tidak memiliki fungsi sama sekali. Metode tersebut secara ad hoc dapat digunakan untuk mendukung keunggulan teori baru yang dirumuskan berdasarkan kesalahan teori pertama. Feyerabend menggantikan teori lama dengan teori baru, Kemudian Feyerabend memilih untuk memfalsifikasi teori sebanyak mungkin metode dan tetap menjaganya. Feyerabend mengatakan bahwa dikekang oleh teori sains modern yang sedang berlaku sama saja seperti dikekang oleh ajaran dogmatik pada zaman pertengahan Eropa.

Sehubungan dengan pendidikan Islam, pluralisme teoritis yang dibawakan oleh Feyerabend memberikan arah yang menjanjikan bagi perkembangan pendidikan Islam itu sendiri. Kondisi semacam ini adalah sebuah keniscayaan. Disinilah penelitian ini akan mencoba untuk mengulas urgensi kajian terhadap konsep anything goes Paul Karl Feyerabend dan implikasinya terhadap pendidikan Islam.

\section{METODE PENELITIAN}

Sesuai dengan karakteristik masalah yang diangkat dalam penelitan ini maka menggunakan Metode Riset kualitatif, yaitu menekankan analisanya pada data deskriptif berupa kata-kata tertulis yang diamati. Pendekatan kualitatif penulis gunakan untuk menganalisis kajian memahami gagasan anything goes Paul Karl Feyerabend dan implikasinya terhadap pendid- 
ikan islam, maka dengan sendirinya penganalisaan data ini lebih difokuskan pada Penelitian Kepustakaan (Library Research), yakni dengan membaca, menelaah dan mengkaji buku-buku dan sumber tulisan yang erat kaitannya dengan masalah yang dibahas. Metode yang digunakan dalam kajian ini menggunakan metode atau pendekatan kepustakaan (library research), menurut Zed dalam (Rahayu, 2020) bahwa studi pustaka atau kepustakaan dapat diartikan sebagai serangkaian kegiatan yang berkenaan dengan metode pengumpulan data pustaka, membaca dan mencatat serta mengolah bahan penelitian.

Jenis penelitian ini adalah penelitian kualitatif. Menurut Ibnu dalam (Nasser, 2021) penelitian kualitatif adalah suatu penelitian yang datanya dinyatakan dalam bentuk verbal dan dianalisis tanpa menggunakan teknik statistik. Berdasarkan beberapa definisi penelitian kualitatif di atas, dapat disimpulkan bahwa penelitian kualitatif adalah suatu penelitian yang datanya dinyatakan dalam bentuk verbal, tidak menggunakan angka dan analisisnya tanpa menggunakan teknik statistik.

1. Objek Penelitian

Dalam penelitian ini objek penelitian terdiri dari 2 (dua), yaitu objek formal dan objek material (Mayasari, 2021). Objek formal dalam penelitian ini berupa data yaitu data yang berhubungan dengan kajian memahami gagasan anything goes Paul Karl Feyerabend dan implikasinya terhadap pendidikan islam. Sedangkan objek materialnya berupa sumber data, dalam hal ini adalah kajian memahami gagasan anything goes Paul Karl Feyerabend dan implikasinya terhadap pendidikan islam.

2. Waktu Penelitian

Penelitian ini dilaksanakan pada bulan Oktober sampai dengan Desember tahun 2021.

3. Teknik Pengumpulan Data

Pengumpulan data yang dilakukan dengan menggunakan teknik dokumentasi yaitu mengadakan survey bahan kepustakaan untuk mengumpulkan bahan-bahan, dan studi literatur yakni mempelajari bahan-bahan yang berkaitan dengan objek penelitian. Teknik pengumpulan data menurut (Bahri, 2021) mengemukakan bahwa merupakan langkah yang paling strategis dalam penelitian karena tujuan untama dari penelitian adalah mendapatkan data. Terdapat beberapa cara atau teknik dalam mengumpulkan data, diantaranya adalah observasi dan dokume- ntasi. Sumber data yang digunakan dalam penelitian ini mencakup data primer dan sekunder. Menurut (Hanafiah, 2021) bahwa data primer adalah data yang dikumpulkan langsung dari individu-individu yang diselidiki atau data tangan pertama. Sedangkan data sekunder adalah data yang ada dalam pustaka-pustaka. Data primer dalam penelitian ini adalah buku-buku terkait kajian memahami gagasan anything goes Paul Karl Feyerabend dan implikasinya terhadap pendidikan islam, dan data sekunder didapatkan dari jurnaljurnal baik nasional maupun internasional.

4. Alat Pengumpulan Data

Dalam penelitian ini, penulis akan menggunakan metode dokumentasi sebagai alat untuk pengumpul data karena penelitian ini adalah penelitian kepustakaan. Dengan kata lain, menurut (Juhji, 2020) bahwa teknik ini digunakan untuk menghimpun data-data dari sumber primer maupun sekunder.

5. Teknik Analisis Data

Analisis data tidak saja dilakukan setelah data terkumpul, tetapi sejak tahap pengumpulan data proses analisis telah dilakukan. Penulis menggunakan strategi analisis "kualitatif", strategi ini dimaksudkan bahwa analisis bertolak dari data-data dan bermuara pada kesimpulan-kesimpulan umum. Berdasarkan pada strategi analisis data ini, dalam rangka membentuk kesimpulan-kesimpulan umum analisis dapat dilakukan menggunakan kerangka pikir "induktif". Menurut (Sugiyono, 2015) bahwa metode pembahasan menggunakan metode deskriptif-analisis, yaitu menjelaskan serta mengelaborasi ide-ide utama yang berkenaan dengan topik yang dibahas. Kemudian menyajikannya secara kritis melalui sumber-sumber pustaka primer maupun skunder yang berkaitan dengan tema.

6. Prosedur Penelitian

Data pada penelitian ini dicatat, dipilih dan kemudian diklasifikasikan sesuai dengan kategori yang ada. Pendekatan yang digunakan adalah pendekatan deskriptif analitis. Menurut (Marantika, 2020) bahwa deskriptif analitis (descriptive of analyze research), yaitu pencarian berupa fakta, hasil dari ide pemikiran seseorang melalui cara mencari, menganalisis, membuat interpretasi serta melakukan generalisasi terhadap hasil penelitian yang dilakukan. Prosedur penelitian ini adalah untuk menghasilkan data deskriptif yang berupa data tertulis setelah melakukan analisis pemikiran (content analyze) dari 
suatu teks. Setelah penulis mengumpulkan bahan-bahan yang berhubungan dengan masalah yang akan di bahas dalam penelitian ini, kemudian penulis menganalisis dan menarasikan untuk diambil kesimpulan.

\section{HASIL DAN PEMBAHASAN}

Dalam pembahasan ini akan dibahas tentang Paul Karl Feyerabend dan Konsep Epistemologi Anything Goes, Epistemologi Pendidikan Islam, dan Konsep Anything Goes Paur Karl Feyerabend dan Implikasinya terhadap Pendidikan Islam.

\section{Paul Karl Feyerabend dan Konsep Epistem- ologi Anything Goes}

Paul Karl Feyerabend lahir di Wina Austria pada tahun 1924, Feyerabend belajar tentang teater di Waimar. Feyerabend sangat tertarik pada drama dan kesenian. Oleh karena itu tidak aneh jika tampak dalam karya-karyanya, terlihat dimana Feyerabend dalam mengajarkan tentang ilmu ilmiahnya dia selalu menggunakan bentuk contoh pada bidang seni.

Dalam Listiyono, disebutkan, bahwa Feyerabend memperoleh gelar Doktor di Wina, Austria dalam bidang Fisika. Feyerabend pada awalnya meyakini bahwa ilmu pengetahuan adalah hal paling hebat serta ada norma hukum yang secara ilmiah dapat dipertanggung jawabkan dan berlaku pada segala tindakan. Feyerabend mengikuti kelas filsafat Karl Popper di London pada tahun 50-an. Ketika itu, Feyerabend masih memegang teguh pemikiran rasionalitasnya, akan tetapi pada saat bersentuhan dengan pemikiran Lakatos, Feyerabend memiliki pemikiran yang berubah drastis. Feyerabend berpendapat bahwa terdapat pelanggaran pada prinsipprinsip pokok mekanika kuantum, oleh karenanya Feyerabend berpendapat semua usaha pencarian hukum universal merupakan ilusi belaka. Pemikiran anarkisme ilmu pengetahuan Feyerabend mencapai puncak pemikiran yang disebut dengan istilah anarkis pada saat berkenalan dengan seorang tokoh yang bernama Weizsacker. Pemikiran anarkisnya tersebut tertuang pada buku karangannya Against Method yang diterbitkan pada tahun 1970. Feyerabend, dapat dikelompokkan sebagai tokoh postmodernisme, jika dilihat dari pola pemikirannya dalam bidang filsafat ilmu. Sehingga bentuk pemikirannya merupakan kritik terhadap paradigma modernisme dan pemikiran Descartes (Renaissance) serta Hegel, yang disebutnya dengan paradigma grand narratives yang dilegimitasikan, yaitu sebuah cara berpikir yang mengeneralisir di dalam menjelaskan multi aspek melalui grand theory (teori dasar) sebagaimana dinyatakan oleh tokoh post-modernism (Santoso, 2006).

Menurut (Mudhofir, 2007) masyarakat pada masa Feyerabend, cenderung ilmu pengetahuan diposisikan sama dengan agama bahkan di atasnya. Pemikiran Paul Feyerabend diklasifikasikan ke dalam paradigma radikal dan anarkis, disebabkan filsafat ilmu itu sendiri tidak berhasil secara valid atau jelas menjelaskan paradigma umum tentang sains serta metode yang membedakan produk-produk yang dihasilkan pseudosains dibandingkan dengan sains murni (Jena, 2010). Seluruh pemikiran Feyerabend dikenal dengan istilah anarkisme epistemologis, yaitu suatu teori epistemologi yang memiliki pandangan, aturan metodologi khusus yang mengatur perkembangan sains atau pengetahuan itu sesungguhnya tidak ada. Karena seharusnya sains dikembangkan melalui regulasi universal tanpa harus merugikan dan membatasi sains itu sendiri (Hasbi, 2021).

Pemikiran Feyerabend sebenarnya juga dipengaruhi oleh Popper melalui teorinya, Falsifikasi (falsification) (Kurdi, 2015). Awalnya, Feyerabend mendukung filosofi dan prinsip falsifikasi yang dipegang teguh Popper. Namun kemudian dia tidak sependapat dengan pikiran-pikiran menjadi prinsip ilmiah gurunya tersebut, bahkan Feyerabend menjadi salah seorang penentang terhadap teori tersebut. Bagi Popper, untuk mendapatkan teori yang benar, setiap teori harus melalui proses falsifikasi. Ketika suatu teori dapat ditemukan titik lemahnya maka teori tersebut menjadi gugur. Popper tidak menyetujui induksi untuk menemukan benar atau tidaknya suatu teori. Menurut teori falsifikasinya, yang terpenting dari sebuah teori adalah apakah ia kuat atau tidak, bukan benar atau salah. Kalau kaum induktivis berpendapat bahwa ilmu pengetahuan berkembang secara akumulatif dari sedikit demi sedikit, maka menurut Popper ilmu berkembang melalui falsifikasi. Teori hanya bisa mendekati kebenaran, tapi tidak bisa seutuhnya benar. Menurut (Popper, 1986), sangat mudah memverifikasi maupun mengkonfirmasi suatu teori, namun yang lebih penting adalah membuktikan bahwa teori itu salah (falsified). 
Menurut Feyerabend, prinsip falsifikasi Popper tidak bisa disebut sebagai satusatunya metode ilmiah untuk kemajuan ilmu pengetahuan. Untuk menemukan kebenaran, tegas Feyerabend, sebuah teori tidak harus dicari kesalahannya (difalsifikasi), melainkan harus diupayakan penemuan teori-teori baru. Teori-teori baru harus terus dikonstruksi dan dikembangkan kemudian dipertahankan. Prinsip ini dikenal dengen 'pluralisme teoritis', Pluralisme teoritis penting untuk menghindari keseragaman yang akan membatasi pemikiran kritis. Ketika teori baru tercipta dan bisa dipertahankan bahkan akan lebih baik dari teori lama, maka teori baru tersebut bisa menggantikan apa yang teori lama telah diberikan, dalam istilah Thomas Kuhn disebut 'perubahan paradigma'. Prinsip falsifikasi Popper, menurutnya, mungkin merupakan metode ilmiah yang pantas digunakan, namun banyak teori baru yang tidak diketahui cara memfalsifikasinya. Baginya, teori-teori yang tidak dapat dilalui dengan proses falsifikasi masih bisa dianggap sebuah kebenaran. Hal ini berbeda dengan Popper yang menganggap bahwa semua teori baru harus melewati proses falsifikasi dan bila gagal melaluinya maka teori tersebut tidak ilmiah dan tidak dapat dibenarkan (tidak dapat diverifikasi). Bagi Feyerabend, setiap teori, baik teori lama maupun yang baru bisa berlaku dan dapat berkembang sesuai dengan cirinya masing-masing, tanpa harus dirivalkan antara satu sama lain, meskipun ia tidak menyangkal kemungkinan dua teori tersebut tidak dapat diperbandingkan (Feyerabend, 1975).

Saat karya Against Method diterbitkan pada tahun 1975, Feyerabend mempertegas pemikirannya tentang epistemologi. Dari buku ini juga muncul frasa antikredo "anything goes" yang sangat identik dengan pemikirannya. Adagium 'Anything goes' menegaskan bahwa hipotesa apa pun boleh dipakai, bahkan yang tidak dapat diterima secara rasional sekalipun, atau berbeda dengan teori yang berlaku dan dihasilkan dari proses eksperimen. Feyerabend menegaskan, kemajuan ilmu pengetahuan tidak hanya ditentukan melalui proses induktif sebagaimana halnya sains normal, melainkan juga secara kontrainduktif (Kurdi, 2015).

Teori-teori baru harus terus dimunculkan, dan tolak ukur keberhasilan dari teori-teori yang baru tersebut tidak harus selalu didasar- kan pada teori lama, ataupun mengacu kepada suatu bentuk yang dianggap mendekati sempurna. Munculnya teori-teori baru tersebut sudah dianggap sebagai suatu kemajuan tentang keilmuan meskipun tidak sesempurna dari teori-teori yang sudah mapan, karena memang sangat sulit untuk memunculkan paradigma-paradigma lain dengan berbagai faktor akademis maupun budaya dan politik yang ikut mengekang jalannya suatu keilmuan (Arifudin, 2021). Sebuah hipotesa atau teori baru tidak harus memenuhi seluruh elemen dari teori lama karena hal tersebut hanya akan menyebabkan teori lama dipertahankan dari pada mencari teori yang benar. Mempertahankan teori lama akan mempersempit pemikiran sehingga tidak bisa membuka lahan teori baru dan mengarahkan ilmu pengetahuan pada subyektivitas, sentimen atau prejudis. Seperti halnya teori kuantum yang pada awalnya ditentang bahkan oleh Einstein sendiri, karena implikasi teori ini menyebabkan ketidakpastian yang sangat mengganggu pikiran, teori baru harus selalu bermunculan secara kompetitif meskipun akan ditentang dengan fakta-fakta yang memberatkan yang berasal dari teori lama. Munculnya teori-teori baru ini dalam pentas ilmu pengetahuan, menurut Feyerabend, merupakan revolusi ilmiah yang sangat penting dan diperlukan untuk kemajuan ilmu pengetahuan itu sendiri. Sehingga saat ini menurut (Febrianty, 2020) perkembangan pengetahuan sangat cepat seiring dengan perubahan zaman.

Feyerabend sebenarnya bukanlah seorang pembenci dengan keberadaan ilmu pengetahuan (anti-science), namun ia hanya mengkhawatirkan potensi rusaknya ilmu pengetahuan karena jatuhnya para ilmuwan dalam keseragaman dan tirani. Ia berusaha menumbuhkan semangat akselerasi mengalirnya keragaman metode keilmuan. Anarkisme metodologis oleh Feyerabend dimaksudkan untuk mendobrak semua tatanan metodologis keilmuan yang seolah sudah terikat erat setiap sekatnya. Menurutnya semua metodologi, bagaimanapun ia dinilai sempurna, pasti memiliki keterbatasan. Karenanya, semua harus diberi kesempatan tanpa dibatasi perannya. Anarkisme Metodologis yang ditawarkannya bukan merupakan bentuk penggulingan status quo keilmuan. Konsentrasinya justru lebih diarahkan pada munculnya paradigma-paradigma lain tanpa menegasikan keilmuan yang telah mendominasi lebih 
dahulu. Kebebasan bisa terjadi bagi status quo maupun metode-metode alternatif lainnya, sehingga keilmuan terus berkembang tanpa limitasi maupun hambatan dalam aspek epistemologis. Inilah yang merupakan karakter khusus dari corak pemikiran Feyerabend (Stokes, 2006).

Sekali lagi, "anything goes" (apapun boleh) disebut Feyerabend sebagai satu-satunya prinsip yang harus dipertahankan dalam setiap tahap perkembangan manusia. Sejatinya, ia tidak berniat untuk menyebarkan pandangannya tersebut, namun pengaruh kuat dari pemikiran-pemikiran Kuhn, dan kemudian gurunya Karl Popper, serta sahabatnya, Imre Lakatos, serta mulai menggeliatnya mazhab fisika kuantum dalam menggoncangkan pondasi klasik New tonian, menyebabkan dirinya harus bergabung ke gelanggang filsafat keilmuan bersama pendekar-pendekar keilmuan tersebut.

\section{Epistemologi Pendidikan Islam}

Pendidikan Islam adalah perpaduan yang menyatu antara pendidikan jiwa, membersihkan ruh, mencerdaskan akal, dan menguatkan jasmani (Maturidi, 2020). Epistemologi pendidikan Islam merupakan ilmu yang mengkaji tentang teori, konsep, manajemen, maupun pelaksanaan pendidikan Islam secara substantive (Makki, 2019). Dilandasi oleh pengertian tersebut, dapat kemudian dipahami bahwa ruang lingkup epistemologi pendidikan Islam dibatasi pada unsur-unsur atau komponen-komponen pendidikan Islam yang diurai secara substantif sehingga berwujud sebagai sebuah teori atau sebuah ilmu.

a) Hakikat Pengetahuan dalam Islam

Ada beberapa istilah yang dipakai untuk menyebutkan ilmu pengetahuan, seperti istilah ilmu, pengetahuan, al-'ilm dan sains. Barangkali untuk menyederhanakan masalah, keempat istilah itu dianggap memiliki makna dan maksud yang sama, sehingga istilah tersebut bebas digunakan dalam wacana keilmiahan tanpa dikaitkan dengan pemahaman yang spesifik dan tertentu. Dalam diskusi ilmiah ternyata masingmasing istilah tersebut mengandung makna yang tidak sama bukan karena faktor asal usul bahasa, tetapi juga substansi dari makna yang dikandungnya. Masing-masing istilah itu memiliki perbedaan jangkauan dan bobot kebenaran setidaknya dalam pandangan para pengkajinya (Qomar, 2007).

Dalam konteks Islam, sains tidak menghasilkan kebenaran absolut. Istilah yang paling tepat untuk mendefinisikan pengetahuan adalah al-'ilm, karena memiliki dua komponen. Pertama, bahwa sumber asli seluruh pengetahuan adalah wahyu atau al-Qur'an yang mengandung kebenaran absolut. Kedua, bahwa metode mempelajari pengetahuan yang sistematis dan koheren semuanya sama-sama valid; semuanya menghasilkan bagian dari satu kebenaran dan realitas, bagian yang sangat bermanfaat untuk memecahkan masalah yang dihadapi. Dua komponen ini menunjukkan, bahwa al-'ilm memiliki akar sandaran yang lebih kuat dibanding sains dalam versi Barat. Akar sandaran al-'ilm justru berasal dari yang Maha Berilmu, Tuhan yang secara teologis diyakini sebagai Sang Penguasa segalanya (Qomar, 2007).

Terkait dengan hakikat pengetahuan islam, epistemologi Islam menjawab bahwa pengetahuan ilmiah adalah segala sesuatu yang bersumber dari alam fisik dan nonfisik. Dengan demikian menjadi jelas bahwa sumber pengetahuan dalam Islam adalah alam fisik yang bisa diindera dan alam metafisik yang tidak bisa diindera seperti Tuhan, malaikat, alam kubur, dan alam akhirat. Alam fisik dan alam non-fisik sama bernilainya sebagai sumber ilmu pengetahuan dalam Islam. Hal ini sangat berbeda dengan epistemologi Barat yang hanya mengakui alam fisik sebagai sumber ilmu pengetahuan. Dengan demikian, sesuatu yang bersifat non-indra, non-fisik, dan metafisik tidak termasuk ke dalam obyek yang dapat diketahui secara ilmiah (Siswanto, 2011).

b) Sumber dan Metode Pendidikan Islam

Dalam hal sumber dan metode ilmu pengetahuan diperoleh, tampaknya ilmu dalam Islam bertentangan dengan filsafat dan sains modern. Kita memandang bahwa ilmu datang dari Tuhan, dan diperoleh melalui sejumlah saluran, indera yang sehat, laporan yang benar yang disandarkan pada otoritas, akal yang sehat dan intuisi. Pada indera dan akal yang sehat tidak terjadi perbedaan yang berarti antara pandangan Barat dan Islam. Bahkan metode ilmiah yang menjadi metode andalan bagi para ilmuwan untuk memperoleh 
ilmu pengetahuan sebenarnya didukung penuh oleh indera dan akal, empirisme dan rasionalisme, induktif dan deduktif. Sedangkan pada otoritas dan intuisi memang terjadi pertentangan mendasar di antara kedua pandangan tersebut.

Dalam tradisi sains Barat, kebenaran yang didasarkan pada otoritas ilmiah tidak bisa diterima, karena penerimaan kebenaran itu berdasarkan pada keahlian seseorang, tanpa kritik dan pengujian, sehingga yang menerima kebenaran itu hanya bersikap apriori. Begitu pula dengan intuisi, seseorang memberikan penilaian tanpa didahului perenungan dan tidak terdapat langkah-langkah yang sistematik dan terkendali, sehingga pengetahuan yang dicapai melalui intuisi sulit dipercaya. Sebaliknya, dalam pandangan Islam otoritas dan terutama intuisi tersebut dapat dipertimbangkan sebagai salah satu saluran ilmu yang bisa didapat oleh manusia (Qomar, 2005).

Islam memandang bahwa sumber utama ilmu adalah Allah. Kemudian Allah memberikan kekuatan-kekuatan atau ilmu tersebut kepada manusia. Secara rinci, Islam mengakui, bahwa sumber pengetahuan ilmu lebih banyak dari sekadar yang diakui oleh ilmuwan Barat. Al-Syaibani mengatakan bahwa pengalaman langsung, pemerhatian dan pengamatan indera hanya sebagian dari sumber- sumber tersebut. Dan masih banyak lagi sumber lain yang paling penting dan paling menonjol adalah percobaan-percobaan ilmiah yang halus dan teratur, renungan pikiran dan pemikiran akal, bacaan dan telaah terhadap pengalaman orang-orang terdahulu, perasaan, rasa hati, limpahan dan akal serta bimbingan ilahi dari orangorang terdahulu. Namun, sumber-sumber ini meskipun banyak macam dan jenisnya, dapat dikembalikan kepada lima sumber pokok, yaitu indera, akal, intuisi, ilham dan wahyu ilahi. Tiga sumber yang terakhir, yaitu intuisi, ilham dan wahyu ilahi, ketiganya pun dapat dibedakan, tetapi bisa saja intuisi dan ilham secara substantif merupakan "wahyu" dalam pengertian yang luas. Sebab, baik intuisi maupun ilham merupakan pemberian dari tuhan seperti halnya kekuatan spiritual (AlSyaibany, 1979).
Sementara itu, A. Yusuf Ali mengutip pendapat Al-Jabari cenderung meringkas sumber pengetahuan itu menjadi tiga saja, yakni wahyu, rasio dan indera (Al-Jabiri, 1993). Menurut pola al-Qur'an, pengetahuan diperoleh melalui wahyu atau penobatan secara ketuhanan, pengetahuan yang absolut (haqq al-yaqîn), rasionalisme atau kesimpulan yang didasari pada keputusan dan penilaian atau pengharapan faktafakta (al-'ilm al-yaqîn), dan melalui empirisme dan persepsi, yaitu dengan menggunakan observasi, eksperimen, laporan sejarah, deskripsi pengalaman-pengalaman kehidupan dan semacamnya ('ain alyaqîn). Ketiga sumber ini mempunyai bobot kebenaran yang berbeda secara bertingkat, yaitu haqq al-yaqîn lebih tinggi dari pada al-ilm al-yaqîn, dan sedangkan al-'ilm al-yaqîn lebih tinggi dari pada 'ain al-yaqîn.

Dalam tradisi pemikiran Islam, ilmu pengetahuan dibangun atas kerja samanya pendekatan akal dan intuisi. Akal mempunyai batas nalar yang kemudian disempurnakan oleh intuisi yang sifatnya pemberian atau bantuan, sedangkan pemberian dari intuisi masih belum tersusun rapi, sehingga dibutuhkan bantuan nalar untuk men sistematisasikan pengetahuan-pengetahuan yang bersifat pemberian tersebut. Dengan pengertian lain, akal membutuhkan intuisi, dan begitu pula sebaliknya, intuisi membutuhkan akal. Keduanya saling membutuhkan bantuan satu sama lain dari pihak lainnya untuk menyempurnakan pengetahuan yang dicapai masingmasing (Al-Syaibany, 1979).

Ringkasnya, ada banyak perbedaan antara wahyu dengan akal atau agama dengan filsafat. Namun, adanya perbedaan tersebut tidak menghalangi keselarasan, keserasian, keharmonisan dan kedamaian di antara keduanya, sementara itu, beberapa konsep metode pendidikan Islam menurut para pemikir pendidikan Islam, antara lain:

\section{1) Al-Ghazali}

Perhatian Al-Ghazali terhadap metode pengajaran lebih dikhususkan bagi pengajaran pendidikan agama untuk peserta didik. Untuk ini ia telah mencontohkan suatu metode keteladanan bagi mental peserta didik, pembinaan budi pekerti, dan penanaman sifat-sifat 
keutamaan pada diri mereka. Metode pengajaran menurut Al-Ghazali dapat dibagi menjadi dua bagian antara pendidikan agama dan pendidikan akhlak, Metode pendidikan agama menurut AlGhazali pada prinsipnya dimulai dengan hapalan dan pemahaman, kemudian dilanjutkan dengan keyakinan dan pembenaran, setelah itu penegakan dalil-dalil dan keterengan-keterangan yang menguatkan akidah.

Al-Ghazali berpendapat bahwa pendidikan agama harus mulai diajarkan kepada peserta didik sedini mungkin. Sebab dalam tahun-tahun tersebut, seorang anak mempunyai persiapan menerima kepercayaan agama semata-mata dengan mengimankan saja dan tidak dituntut untuk mencari dalilnya. Sementara itu berkaitan dengan pendidikan akhlak, pengajaran harus mengarah kepada pembentukan akhlak yang mulia. Al-Ghazali mengatakan bahwa akhlak adalah suatu sikap yang mengakar di dalam jiwa yang akan melahirkan berbagai perbuatan baik dengan mudah dan gampang tanpa perlu pemikiran dan pertimbangan (Al-Ghazali, 2000).

2) Ibnu Khaldun

Menurut Ibn Khaldun bahwa mengajarkan pengetahuan kepada peserta didik hanyalah bermanfaat apabila dilakukan dengan berangsur-angsur, setapak demi setapak dan sedikit demi sedikit. Pertama-tama harus diberi pelajaran tentang soal-soal mengenai setiap cabang pembahasan yang dipelajari. Keterangan-keterangan harus diberikan secara umum sesuai dengan kekuatan pikiran dan kesanggupan untuk menerima pelajaran. Setelah memahami hal itu barulah mempelajari hal hal pokok tentang seluk beluknya (Nata, 2014).

3) Az-Zarnuji

Prinsip metodologi pendidikan selalu menunjukan aspek berganda. Satu aspek menunjukan anak belajar, diaspek lain menunjukan guru mengajar. Untuk mengadakan tinjauan terhadap pikiran Syekh Az-Zarnuji, maka terebih dahulu dikemukakan dua prinsip pendidikan modern untuk dijadikan patokan, Metode belajar tergantung pada kualitas mental tiap individu. Beberapa kualitas mental itu lebih kurang bersamaan diantara anak-anak. Hal ini memungkinkan untuk menyusun metode umum dalam mengajar sehingga anak-anak dapat diorganisir ke dalam kelas. Namun, perlu diingat secara mendetail anak-anak itu berbeda satu sama lain baik fisiknya, tempramennya ataupun kecerdasanya. Karena itu masih diperlukan metode mengajar yang dapat memenuhi kebutuhan khusus tiap individu.

Prinsip pertama, menghafal dan memahami. Az-Zarnuji mengemukakan cara belajar menghafal dan memahami, karena kedua cara ini berkaitan dengan sifat khusus individu. Kemudian mengulang dan menghafal. Cara ini sudah umum dalam pendidikan Islam. Belajar satu huruf mengulang ribuan kali, makin bayak mengulang makin baik. Lalu menghafalkan diluar kepala untuk memudahkan menghafal, para ulama menyusun mata pelajaran dalam bentuk syair.

Selanjutnya memahami dan mencatat, sebelum dihafal haruslah lebih dahulu dipahami sesudah hafal dan paham barulah dicatat. Mencatat sebelum menghafal menuru Az-Zurnuji menyebabkan kelelahan jiwa, mengurangi kecerdasan dan membuang waktu (Az-Zarnuji, 2004), prinsip kedua, muzakarah, munazarah dan mutharahah. Muzakarah adalah metode soal jawab antara sesama peserta didik. Peserta didik yang satu menyampaikan soal ke yang lain dengan maksud membangkitkan ingatan terhadap pelajaran yang sudah diterima. Semantara itu, munazarah diambil dari kata nazhara yang berarti pandangan sehingga dapat dikatakan sebagai metode diskusi kelompok kecil (small group discussion) jumlah anggota 5-6 orang. Masing-masing anggota mempunyai pandangan (nazhar) untuk menyampaikan pandanganya kepada orang lain. Dalam kelompok ini lahir kerjasama antara anggota kelompok untuk membahas materi yang telah diterima.

Selanjutnya, mutharahah berasal dari kata tharaha yang menurut bahasa berarti melontari. Metode ini dapat din- 
amakan metode kelas (class discussion). Anggota yang satu mengkritik pendapat anggota yang lain jika diskusi kelompok dipimpin anggota. Dalam diskusi ini sebuah masalah sudah disodorkan terlebih dahulu untuk dipecahkan secara bersama (Arifudin, 2018), Kesemuanya ini bersifat musyawarah karena dilakukan lebih dari satu orang untuk mencari kebenaran dan kebenaran itu dapat ditemukan dengan pemikiran masingmasing anggota.

\section{Konsep Anything Goes Paur Karl Feyera- bend dan Implikasinya terhadap Pendi- dikan Islam}

Melalui konsep anything goes ("apapun boleh"), Feyerabend ingin menghidupkan kembali ilmu pengetahuan sebagai ekspresi kebebasan kaum intelektual dalam menyuarakan hasil pemikirannya. Dalam konteks pendidikan Islam, prinsip "apapun boleh" ini telah mewarnai setiap metode seperti dijelaskan di atas. Beberapa metode pendidikan Islam di atas dihadirkan oleh para ilmuan pendidikan Islam dengan ciri khas masingmasing. Satu metode ditawarkan kemudian muncul metode yang lain untuk mengimbanginya. Metode tertentu yang pernah mendominasi panggung pendidikan Islam kemudian metode yang lain hadir sebagai bentuk "perlawanan" sekaligus kritik atas kekurangan atau kelemahan metode pertama, dan begitu seterusnya.

Sebagian pemikir pendidikan Islam juga menggunakan pendekatan tertentu dalam menghadirkan metodenya, kemudian pemikir lain hadir memakai pendekatan yang lain pula. Hadirnya beragam metode itu sebagai bentuk "kontestasi intelektual" dalam diskursus pendidikan Islam. Semuanya berada dalam prinsip "anything goes" (apapun boleh), sehingga satu metode tidak boleh "mengebiri" metode atau pendekatan yang lain.

Namun, demikian, ada sebagian kelompok yang memaksakan monopoli atas metode tertentu. Metode tertentu dipandang paling benar sehingga paling layak digunakan dan dipertahankan dari pada metode yang lain. Ada anggapan di kalangan pondok pesantren bahwa metode Az-Zarnuji, misalnya, lebih baik dan paling benar dari metode yang lain. Selain itu, metode Az-Zarnuji juga dinilai sebagai satu-satunya yang paling layak dijadikan pegangan karena telah menjadi tradisi pembelajaran Islam di pondok pesantren. Pembatasan semacam itu dapat mengganggu panggung kontestasi pendidikan Islam yang dapat berdampak pada tersendatnya kemajuan ilmu-ilmu pendidikan Islam. Apalagi, tidak sedikit para ahli yang memandang bahwa pendidikan dinilai sebagai sesuatu bersifat dinamis (Hermawan, 2020).

Dalam perkembangan ilmu pendidikan Islam, muncul beberapa sarjana muslim yang merasakan kegelisahan akan mandegnya metode pendidikan Islam. Mereka menawarkan epistemologi maupun metodologi yang dinilai mampu memberikan solusi dalam pendidikan Islam. Sederet tokoh yang bisa dimasukkan dalam konteks ini yaitu pemikiran K.H. Hasyim Asy'ari dan K.H. Ahmad Dahlan, Hasan Langgulung dan Zakiyah Darajat. K.H. Hasyim Asy'ari berpandangan bahwa dalam pendidikan Islam etika/akhlak harus diutamakan oleh pelaku pendidikan demi mencapai kesuksesan dalam belajar. Hal ini tercermin dalam karyanya, 7 (tujuh) dari 8 (delapan) bab membahas mengenai etika/ akhlak bagi pelaku pendidikan. Hal ini dikarenakan pendidik dan peserta didik haruslah memiliki etika atau akhlaq yang baik, baik ketika dalam mengajar maupun ketika santai di luar (dimasyarakat) (Hasyim, 2015).

Pendapat K.H. Ahmad Dahlan mengenai pendidikan Islam adalah pendidikan bertitik tolok dari upaya pengembangan akal perjalanan pendidikan harus melalui proses yang pada akhirnya akan bermuara pada tumbuhnya kreatifitas dan inovasi, semua itu memberikan implikasi bagi warga masyarakat untuk memiliki semangat pembaharuan (Iswanti., 2010). KH. Ahmad Dahlan lebih menekankan pendidikan Islam yang bersifat inklusif. Gagasan ini dimulai dari perkembangan ilmu pengetahuan dan teknologi (iptek) meimbulkan problem berbeda dengan masa kenabian dan generasi salafi. Pada akhirnya menciptakan pembaharuan yang dibawa Kiai Ahmad Dahlan yang dijadikan sebagai fungsionalisasi ajaran Islam dengan sikap terbuka dan tradisi lokal, peradaban sekuler dan duniawi ialah ajang kreativitas dalam merealisasi fungsi utama manusia sebagai khalifah.

Sementara itu, (Langgulung, 2002) tentang pendidikan Islam kontemporer mengemukakan bahwa belajar sebagai proses untuk mengembangkan berbagai kompetensi peserta didik, mensinergikan berbagai ilmu, kese- 
hatan mental juga aspek yang penting untuk dikembangkan dalam pendidikan Islam selain aspek spiritual, pengetahuan dan sosial. Dzakiah Darajat dalam (Tanjung, 2019) mempunyai pandangan bahwa pendidikan Islam harus mencetak manusia yang sesuai fitrahnya yakni sebagai Abdullah dan Khalifah Allah, mensinergikan aspek intelektual dan spiritual serta moral, psikologi sufistik sebagai aspek yang perlu dikembangkan di dalam pendidikan Islam.

Tawaran metode dan pendekatan yang dianggap baru tersebut sebagai bentuk dinamika yang harus diapresiasi perkembangannya. Artinya, lahirnya metode baru dalam pendidikan Islam tidak perlu dihindari apalagi dilarang. Hadirnya tokoh pendidikan Islam kontemporer menegaskan bahwa pendidikan harus terus mengalami perkembangan dalam keilmuan tanpa boleh ada yang membatasi maupun menutup peluang itu. Lahirnya beragam konsepsi pendidikan yang telah ditawarkan oleh para ahli pendidikan Islam tidak boleh menjadi penghalang bagi siapapun di setiap generasi untuk terus berkarya melahirkan teoritisasi pendidikan Islam yang kreatif demi menjawab tantangan zaman, selama dia mampu melakukannya.

\section{SIMPULAN DAN SARAN}

\section{A. Simpulan}

Berdasarkan pemaparan pada penelitian memahami gagasan anything goes Paul Karl Feyerabend dan implikasinya terhadap pendidikan islam dapat disimpulkan bahwa pemikiran Feyerabend tentang anarkisme epistemologi dapat melahirkan perkembangan dalam pendidikan Islam. Selain itu, prinsip anything goes yang dibangun dalam pemikirannya juga dapat menghilangkan atau paling tidak mengurangi terjadinya monopoli dari satu metode terhadap metode yang lain. Namun demikian, Anarkisme Epistemologi Feyerabend dapat menimbulkan masalah dalam perkembangan pendidikan Islam, yakni lahirnya kebebasan berpikir yang terlalu liar.

\section{B. Saran}

Pembahasan terkait penelitian kajian memahami gagasan anything goes Paul Karl Feyerabend dan implikasinya terhadap pendidikan islam dalam penelitian ini masih sangat terbatas dan membutuhkan banyak masukan. Saran untuk penulis selanjutnya adalah mengkaji lebih dalam dan secara kompre- hensif terkait kajian memahami gagasan anything goes Paul Karl Feyerabend dan implikasinya terhadap pendidikan islam.

\section{DAFTAR RUJUKAN}

Al-Ghazali. (2000). Ihya Ulumuddin. Semarang: Toha Putra.

Al-Jabiri. (1993). Bunyat al-'Aql al-'Arabi. Beirut: al-Markaz al-Tsaqafi al- Arabi.

Al-Syaibany. (1979). Falsafah Pendidikan Islam, terj. Hasan Langgulung. Jakarta: Bulan Bintang.

Arifudin, O. (2018). Pengaruh Pelatihan Dan Motivasi Terhadap Produktivitas Kerja Tenaga Kependidikan STIT Rakeyan Santang Karawang. MEA (Manajemen, Ekonomi, \& Akuntansi), 2(3), 209-218.

Arifudin, O. (2020). Manajemen Risiko. Bandung : Widina Bhakti Persada.

Arifudin, 0. (2021). Manajemen Strategik Teori Dan Implementasi. Banyumas: Pena Persada.

Asmedy, A. (2021). Perbandingan Hasil Belajar Matematika Siswa yang diajar dengan Model Pembelajaran Possing Problem Berkelompok dan Metode Ceramah. Jurnal Inovasi, Evaluasi Dan Pengembangan Pembelajaran (JIEPP), 1(2), 69-75. https://doi.org/10.54371/iiepp.v1i2.107

Az-Zarnuji. (2004). Kitab Ta 'lim Mutaalim Thoriiq at-Taallum. al dar Soudaniafor Books.

Bahri, A. S. (2021). PENGANTAR PENELITIAN PENDIDIKAN (Sebuah Tinjauan Teori dan Praktis). Bandung : Widina Bhakti Persada.

Bairizki, A. (2021). Manajemen Perubahan. Bandung : Widina Bhakti Persada.

Febrianty, F. (2020). Kepemimpinan \& Prilaku Organisasi Konsep Dan Perkembangan. Bandung: Widina Bhakti Persada.

Feyerabend. (1975). Against Method: Outline of an Anarchic Theory of Knowledge. London: New Left Book. 
Hanafiah, H. (2021). Pelatihan Software Mendeley Dalam Peningkatan Kualitas Artikel Ilmiah Bagi Mahasiswa. Jurnal Karya Abdi Masyarakat, 5(2), 213-220.

Hasbi, I. (2021). Administrasi Pendidikan (Tinjauan Teori Dan Praktik). Bandung: Widina Bhakti Persada.

Hasyim. (2015). Strategi Mengajar Perspektif K.H. M. Hasyim Asy'ari dalam Kitab Adab Al'Alim wa Al-Muta'allim. Tarbiyatuna: Jurnal Pendidikan Islam, 8(2), 239-271.

Hermawan. (2020). Konsep Kurikulum dan Kurikulum Pendidikan Islam. Jurnal Mudarrisuna, 10(1), 34-44.

Irwansyah, R. (2021). Perkembangan Peserta Didik. Bandung : Widina Bhakti Persada.

Iswanti. (2010). Pendidikan Islam Menurut Pemikiran K.H. Ahmad Dahlan. Salatiga: IAIN Salatiga.

Jena. (2010). Dimensi Dinamis Ilmu. Jakarta: Gramedia.

Juhji. (2020). Manajemen Humas Sekolah. Bandung: Widina Bhakti Persada.

Kuhn. (1962). The Structure of Scientifc Revolution. Chicago: University of Chicago Press.

Kurdi. (2015). Epistemologi Anarkisme Paul Feyerabend dalam Studi Ilmu Tafsir AlQuran. Religia, 18(1), 1-26.

Langgulung. (2002). Peralihan Paradigma Dalam Pendidikan Islam dan Sains Sosial. Jakarta: Gaya Media Pratama.

Makki. (2019). Epistemologi Pendidikan Islam: Memutus Dominasi Barat terhadap Pendidikan Islam. Al-Musannif: Journal of Islamic Education and Teacher Training, 1(2), 110-126.

Marantika, N. (2020). Manajemen Humas Sekolah. Bandung: Widina Bhakti Persada.

Maturidi. (2020). Epistemologi dan Ontologi Pendidikan Islam. At-Tarbawi: Jurnal
Pendidikan, Sosial Dan Kebudayaan, 12(2), 132-139.

Mayasari, A. (2021). Implementasi Sistem Informasi Manajemen Akademik Berbasis Teknologi Informasi dalam Meningkatkan Mutu Pelayanan Pembelajaran di SMK. JIIPJurnal Ilmiah Ilmu Pendidikan, 4(5), 340345. https://doi.org/10.54371/jiip.v4i5.277

Mudhofir. (2007). Pengenalan Filsafat: Filsafat Ilmu. Yogyakarta: Penerbit Liberty.

Na'im, Z. (2021). Manajemen Pendidikan Islam. Bandung: Widina Bhakti Persada.

Nasser, A. A. (2021). Sistem Penerimaan Siswa Baru Berbasis Web Dalam Meningkatkan Mutu Siswa Di Era Pandemi. Biormatika: Jurnal Ilmiah Fakultas Keguruan Dan Ilmu Pendidikan, 7(1), 100-109.

Nata. (2014). Perspektif Islam Tentang Strategi Pembelajaran. Jakarta: Kencana.

Nurhasanah, E. (2021). Peran Orang tua dalam Membimbing Anak Usia Sekolah Dasar di Rumah pada Masa Pandemi Covid-19. Jurnal Inovasi, Evaluasi Dan Pengembangan Pembelajaran (JIEPP), 1(1), 11-18. https://doi.org/10.54371/jiepp.v1i1.75

Popper. (1986). Objective Knowledge, A Revolutionary Approach. New York: Clarden Press Oxford.

Qomar. (2005). Manajemen Pendidikan Islam. Jakarta: Erlangga.

Qomar. (2007). Epistemologi Pendidikan Islam dari Metode Rasional hingga Metode Kritik. Jakarta: Erlangga.

Rahayu, Y. N. (2020). Program Linier (Teori Dan Aplikasi). Bandung : Widina Bhakti Persada.

Rinjani, C., Wahdini, F. I., Mulia, E., Zakir, S., \& Amelia, S. (2021). Kajian Konseptual Model Pembelajaran Word Square untuk Meningkatkan Hasil Belajar Siswa. Jurnal Inovasi, Evaluasi Dan Pengembangan Pembelajaran (JIEPP), 1(2), 52-59. https://doi.org/10.54371/jiepp.v1i2.102 
Santoso. (2006). Seri Pemikiran Tokoh: Epistemologi Kiri. Yogyakarta: Ar-Ruzz Media.

Siswanto. (2011). Epistemologi Pendidikan Islam. Cendekia: Jurnal Kependidikan Dan Kemasyarakatan, 9(1), 1-11.

Sofyan, Y. (2020). Peranan Konseling Dosen Wali Dalam Meningkatkan Motivasi Belajar Mahasiswa Di Perguruan Tinggi Swasta Wilayah LLDIKTI IV. Jurnal Bimbingan Dan Konseling Islam, 10(2), 237-242.

Stokes. (2006). Philosophy: 100 Essensial Thinkers. New York: Enchanted Lion Books.
Sugiyono. (2015). Metode Penelitian Pendidikan (Pendekatan Kuantitatif,. Kualitatif dan $R \& D)$. Bandung : CV. Alfabeta.

Tanjung, R. (2019). Manajemen Pelayanan Prima Dalam Meningkatkan Kepuasan Mahasiswa Terhadap Layanan Pembelajaran (Studi Kasus di STIT Rakeyan Santang Karawang). MEA (Manajemen, Ekonomi, \& Akuntansi), 3(1), 234-242.

Ulfah, U. (2022). Kepemimpinan Pendidikan di Era Disrupsi. JIIP-Jurnal Ilmiah Ilmu Pendidikan, 5(1), 153-161. 